\title{
INIMITABLE-BASED INNOVATIVE ENTREPRENEURSHIP AS MEDIATION CONCEPTS OF INFORMATION TECHNOLOGY ROLES ON ORGANIZATIONAL PERFORMANCE
}

\author{
Iwan HERMAWAN ${ }^{1} 12^{*}$, Suharnomo SUHARNOMO${ }^{1}$, Mirwan Surya PERDHANA ${ }^{1}$ \\ ${ }^{1}$ Faculty of Economics and Business, Universitas Diponegoro, Semarang, Indonesia \\ ${ }^{2}$ Department of Business Administration, Politeknik Negeri Semarang, Semarang, Indonesia
}

Received 25 June 2020; accepted 27 July 2020

\begin{abstract}
The creative economy paradigm emphasizes the importance of ideas and intellectual property as an entrepreneurial prerequisite for being able to survive in fierce global competition. Today, an entrepreneur is required to create products with unique differences in power over competitors to stay alive in the industry. Organizational external and internal resources such as Information Technology (IT) and local culture are strategic asset sources that have an important role in building business performance. This study departs from the gap of research that is still inconclusive about the effect of IT on Organizational Performance (OP). The research direction offers novelty concepts from the perspective of resourcebased entrepreneurship theory. This paper offers the concept of Inimitable-based Innovative Entrepreneurship (IBIE), which in its ontology IBIE is the application of innovation distribution of product attributes sourced from the local nuances of design so that it becomes an iconic product that is difficult to emulate. The direction of this study will examine the concept of IBIE at the organizational level. The sample is 138 creative entrepreneurs who are SME owners who base their needs on design images that are always renewable. Hypothesis testing carried out shows empirically the IBIE variable has been able to act as a full mediation variable to bridge the gap between IT (Beta $(\beta)=0.747)$ and OP $(\beta=3.341)$. IBIE becomes a concept that fills the space of the influence of IT on OP in the body of knowledge in the entrepreneurship domain.
\end{abstract}

Keywords: information technology, organizational performance, entrepreneurship, creative industry.

JEL Classification: L26, M30.

\section{Introduction}

Studies on the effect of IT on OP have attracted many researchers in the field of management (Almazán et al., 2017; Barba-Sanchez et al., 2018; Rajapathirana \& Hui, 2018) that IT is a knowledge infrastructure that is crucially attached to organizations to create a competitive advantage. But, the study of IT on OP remains contradictory results. Previous studies that demonstrated the strategic role of IT in organizations revealed that IT is a strategic asset for building organizational repositories (Choe, 2016; Ramadan et al., 2017; Roldán et al., 2018). IT is defined as the technical systems within an organization, which determines how knowledge travels and accessed (Chang \& Chuang, 2011). IT capabilities such as database interfaces, data entry screens, and reports provide knowledge about how business transactions are to be conducted. So the role of IT allows the integration of information and knowledge in the organization and providing the creation, transfer, storage, and protection of knowledge resources in the organization (Matin \& Sabagh, 2015; Miranda et al., 2011). Cuevas-Vargas et al. (2016), Mills and Smith (2011) underline the findings of most researchers regarding the existence of a significant positive relationship between IT and performance. IT capabilities can be considered as the main requirements for value creation, enabling organizations to defeat competitors (Barba-Sanchez et al., 2018; Meiliene et al., 2015). Sharma and Intan (2008) in their study of IT in the context of infrastructure development in several developing countries, including Indonesia, emphasized the strategic value of infrastructure development. Technology infrastructure will make it possible for countries to facilitate the management of large information flows from the community and redistribute it to the community as social knowledge. This is an achievement in national assets. Thus, the availability and reliability of network infrastructure will encourage local entrepreneurs to use it as an input resource to absorb viral information

${ }^{*}$ Corresponding author. E-mail: iwanpolines@gmail.com

Copyright $\odot 2021$ The Author(s). Published by Vilnius Gediminas Technical University

This is an Open Access article distributed under the terms of the Creative Commons Attribution License (http://creativecommons.org/licenses/by/4.0/), which permits unrestricted use, distribution, and reproduction in any medium, provided the original author and source are credited. 
and convert it into knowledge in order to build a Research and Development (RND) process to build new creative products. Social information networks also have other important impacts on building market access networks, this is what is meant as open innovation (Hermawan et al., 2016).

Indonesia is a country with robust growth of internet media users in the last two decades, Indonesian internet users at the beginning of the second millennium which only $9.5 \%$ of 211 million population or around 2 million netters, now has become $53.15 \%$ with active netter reaching 143, 2 million residents. Today, the ease of internet access, affordable subscription prices have encouraged entrepreneurs in Indonesia to accelerate IT readiness, erode to encourage technology savvy to entrepreneurs. More than $74 \%$ of Indonesian entrepreneurs have adopted IT in their daily business lives that are done mobile (Hermawan et al., 2016). Furthermore, the emergence of new issues such as the creative economy paradigm, Blue Ocean, canvas business and industry 4.0 has inspired the importance of organizational needs on a brilliant idea, fresh ideas, patents, and other intellectual property as absolute capital which is a prerequisite for survival in the industry. The organization always provides new ideas to create a difference in their creative products. It is what makes the role of IT and social networks as vital as the current input capability (Hermawan et al., 2020). Ulrich et al. (2012) recognize the importance of the Human Resources Management (HRM) role as an organizational agent that manages services and disseminates technology adoption to all entities. HRM currently does not only focus on its role as administration and line management support, further known as HR out-site in, and becoming proponent technology manifestation in the organization. Departing from this termination, IT as a knowledge infrastructure, for example, hardware, software, and application system is only a tool in the organization. IT necessitates being dynamized with approaches such as human capital and learning to expand its role in building organizational creativity. It means that IT must now be firmly controlled by entrepreneurs as tech-savvy competencies in underlying the design process, production process, marketing penetration and building teamwork synergy in organizations (Davi et al., 2013; Medina-Quintero et al., 2015; Sinkovics et al., 2015). Entrepreneurs master IT for the purpose of acquiring, transferring, and storing knowledge and converting it into organizational performance achievements (Cantino et al., 2017). The issue of the actual geolocation of business phenomena in Indonesia today such as the collapse of many shops, malls, and supermall which are very strong capital due to unable to compete with micro-scale SMEs that occupy small places and with few employees. Microscale online businesses can be run by ignoring complex manufacturing processes, and being able to produce just in time is easy to do now. The fact that infrastructure is obscuring encourages to encourage the Indonesian microindustry to grow into a great power that has a competitive advantage (Hermawan et al., 2019a). Even though Indonesia is a country starting to be defined as a developed country, infrastructure development continues to grow and has encouraged micro-businesses to have the readiness to use technology where most entrepreneurs have run their businesses mobile (Hermawan et al., 2019a), meaning SMEs have escaped the anxiety of using technology. SMEs are creative, look for issues of viral information, build cohesive work teams and also interact with customers to disseminate business profile information and products via emarketplace and e-shop mobile. The micro-industry based on digital economic innovation like this has strengthened the rate of economic growth in Indonesia 2015-2018 $(+5 \%)$. Creative SMEs adopt the ornaments, letters and nuances of local cultural wisdom placed in their products to provide distinctiveness and competitive advantage. IT capability to design batik fashion, advertising, software and handicraft. IT and local cultural heritage become a synergy (Hermawan et al., 2018; Matheson, 2006). The micro-business is now becoming flexible to compete in the open market has become strong evidence of how important intangible assets are strengthened by the role of IT as a resource to create a unique difference in the era of a knowledge-based economy.

The resource-based view (RBV) perspective realizes the importance of intangibles such as customer orientation, human capital, and organizational knowledge by offering to explore RBV theory in depth and re-examine the role of IT against OP. Research on the influence of both is still inconclusive and becomes a contradictory gap (Müller-Bloch \& Kranz, 2015). The results of this study create two opposing poles of opinion. The first pole, study results (Alaarj et al., 2016; Chiu \& Chen, 2016; Matin \& Sabagh, 2015; Mendejin \& Arastekhoo, 2017; Mills \& Smith, 2011; Roldán et al., 2018; Smith, 2008; Tippins \& Sohi, 2003) have empirically proven that IT has no significant influence on performance. At this pole (Powell \& Dent-Micallef, 1997) which is a reference for researchers at the first pole, has expressed his opinion that IT is a resource that cannot stand alone, IT needs other concepts that must be elaborated in order to leverage its role significantly towards OP while at other poles studies (BarbaSanchez et al., 2018; Torkestani et al., 2014; Yunis et al., 2018; Zhang et al., 2016) prove the significant influence between IT on OP. This empirical fact provides a line of argument in the opinion of (Teece, 1986) which confirms that the absence of IT will make the organization blunt because IT is an instrument that is very easy to copy-paste to directly provide a competitive advantage. During the last decade, the two poles of opinion (Powell \& Dent-Micallef, 1997) and Teece (1986) have crystallized and become an inconclusive gap.

The direction of this paper will reveal the empirical facts of the role of IT towards OP in creative SMEs based on the need for strong design innovations, such as fashion and publishers spread across Denpasar, Jogja and Surakarta in Indonesia. The attractiveness of this study location is 
because the three cities have kings, palaces, typographic characters, and distinctive ornament designs that become local cultural heritage. The cultural wealth at this sample location should be an advantage that is elaborated with IT capabilities and a mix of capital that encourages SMEs to utilize the richness of this cultural wealth as a unique creative product attribute in the context of Local Heritages Design Acquisition (LHDA). The novelty of this research is to examine the gap with the perspective of RBV Theory which formulates the concept of IBIE. IBIE is based on the concepts of Inimitable and Innovative Entrepreneurship. Inimitable is a concept of an entrepreneurial approach that was introduced in Barney's article (Barney, 1991). Inimitable is the ability to make products that are not easily imitated, acquired from the capability of human capital assets. This intellectual asset was built accumulatively based on the historical repository of individual tacit-expository knowledge throughout their work-life. Innovative Entrepreneurship is a concept that focuses entrepreneurs on new ideas to produce products that are acceptable in the market (Baumol, 2010; Lumpkin \& Dess, 1996). IBIE which is synthesized from the concept of Inimitable and the concept of Innovative-Entrepreneurship is a novelty offered in this paper to bridge the influence of IT on OP. To achieve the objectives in this paper, a series of hypotheses is offered based on the conclusions of previous studies, in the form of the influence of IT on OP.

\section{Research model and hypothesis}

The research model emphasizes that entrepreneurship is a complex part of a resource-based framework, in that concept entrepreneurship starts from focusing on mapping business assets that can be used as resources (Alvarez \& Busenitz, 2001; Kellermanns et al., 2016). The concept of entrepreneurship focuses on identifying problems, recognizing resource opportunities for creating heterogeneous output as a unique domain. Heterogeneity is a general attribute of entrepreneurship in the form of beliefs about the value of a resource. The sample object is the creative industry, the creative industry is a business activity that bases on individual creativity, skills and talents, and the potential for intellectual property rights (Hermawan et al., 2016; Pareja-Eastaway, 2016). In the conceptual model that was built (Figure 1) there are five concepts. IT and LHDA, both of which are input resource capabilities, IBIE in their capabilities as processing concepts, and OP as the output of model achievements.

\subsection{IT as a determinant of $\mathrm{OP}$}

IT has a strategic role in driving OP achievements, with this role, IT can be relied upon as a medium that triggers competitive advantage (Ainin et al., 2016; Bilan et al., 2019; Chege et al., 2020; Feeny \& Ives, 1990; Kettinger et al., 1994) although in many studies it cannot prove the positive relationship between the two as in researches (Matin \& Sabagh, 2015; Mills \& Smith, 2011; Roldán et al., 2018), even though IT capability is a necessity for the availability of organizational knowledge, but some studies that investigate the relationship between IT and OP still do not convincing and has failed to explain directly the relationship between the two (Emadzadeh et al., 2013). Powell and Dent-Micallef (1997), cited by many researchers in this study, have confirmed that IT cannot directly increase OP. IT is an element that needs to be aligned with other elements in the organization in order to be able to have a significant impact on OP (Luftman et al., 2017; Roldán et al., 2018). So that the existence of IT needs to be elaborated with other elements, IT needs to be elaborated with organizational elements such as human capital. The first hypothesis in this paper is that there is no significant influence between IT and OP.

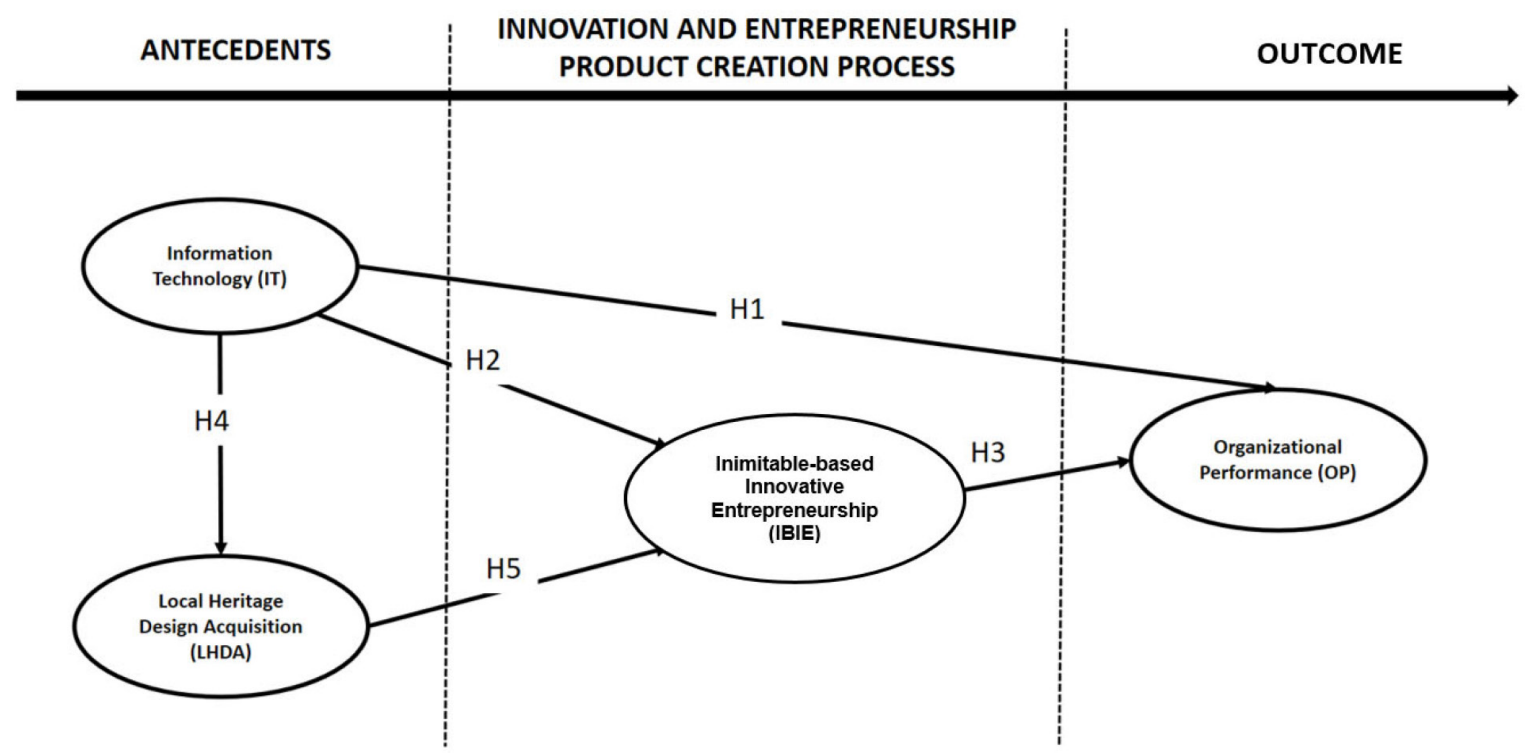

Figure 1. Proposed concepts of entrepreneurial and design acquisition 


\subsection{IT as a determinant of IBIE}

IBIE is a novelty offered and will be tested in this paper. IBIE emphasizes the achievement of innovation in it, IBIE crystallized from the concept of entrepreneurial orientation (Baumol, 2010; Kreiser et al., 2013; Lumpkin \& Dess, 1996). IBIE is an entrepreneur who puts innovation as the basis of work-life. Entrepreneurs are inventors with different power-oriented availability of their products to competitors. Entrepreneurs emphasize selfesteem in the form of design independence, explicitly innovation is the independence of designing and building new products. The anti-plagiarism concept inherent in design is the entrepreneurial way of life. IT which has the root capability to create knowledge, transfer knowledge and storage knowledge will provide support in entrepreneurial orientation. As in previous studies (Todd \& Javalgi, 2007) provide empirical evidence that IT has a significant effect on entrepreneurship (Abbas, 2018; Cantino et al., 2017; Cruz et al., 2015; Valentina et al., 2015). Starting from a common understanding, entrepreneurship has a dynamic nature, so that entrepreneurial orientation becomes a process that is used to enable the capability of input resources such as infrastructure so that it becomes dynamic. Good infrastructure capability will encourage the development of innovation. Variants of the wealth of ideas, variety of designs and access to sources of knowledge used for creation will be built by the RBV, such as IT capabilities. Designing and creating an intellectual property from entrepreneurial products that are not easily imitated is the reliability of the functional IT role. So, the better IT adoption, the easier it is for entrepreneurs and creates new products that are inimitable. The second hypothesis in this paper is that IT has a significant influence on IBIE.

\subsection{IBIE as a determinant of $O P$}

The IBIE concept emphasizes the importance of entrepreneurs using all tangible and intangible resources to form innovative characters. IBIE will produce a pioneer in market trends, entrepreneurs who play trendsetters, create product trending and make a viral product. Previous studies have shown that there is a significant influence between entrepreneurship variables on OP (Matsuno et al., 2002; Wang, 2008; Zhao et al., 2011). Even though the object in the previous study was not in a work environment based on creativity and design, this is strong enough to prove the novelty of the IBIE concept will have a significant influence on OP. The third hypothesis is that there is a significant effect of IBIE on OP.

\subsection{IT as a determinant of LHDA}

The LHDA referred to in this paper is in the form of ornaments, colors, artifacts, geo-culture, and characters, which are the local cultural characteristics where the
SMEs carry out the production process and expressly create a unique design differentiation as a condition for SMEs to survive in the context of the creative economy. Many studies are aware of the importance of local cultural attributes as an external context in their role of strengthening the brand image of a product (Hamzaoui \& Merunka, 2006; Lu et al., 2011; Schoales, 2006), with the role of IT will encourage more value from cultural elaboration and creative products (Omeluzor et al., 2014). Culture becomes the identity of a country's national assets. Cultural attributes are often found in the creative industries such as in movies, restaurants, handicrafts, game consoles, software, which are most easily found through ornamentation of design and typographic motifs. Cultural ornaments embedded in literary products will make national identity as brand awareness stronger, such as Chinese films, Korean pop music, Japanese restaurants, western food such as pizza and spaghetti are easily recognizable because they acquire local culture strongly and are embedded as attributes and become an identity. IT takes a more active role in order to optimize the local culture. A good IT capability, it will be easier for entrepreneurs to modify, arrange and create distinctive ornaments that are rooted from local heritages into product identity, of course with conversion through applications such as movie maker, vector designer, and image processing. The better it is applied in the organization, the better the entrepreneur's capability to absorb local ornaments, artifacts, and designs that will be converted into creative design modifications (Țurcan et al., 2010; Zheng, 2011). The fourth hypothesis is the significant influence of IT on LHDA.

\subsection{LHDA as a determinant of IBIE}

LHDA is a process of mapping and managing local cultural heritage design ornaments to be acquired as product attributes. Product identity automatically reinforces the unique value of new creative products. The acquisition of local heritages design will be a reinforcement of a product design that is not easily imitated. The identity and uniqueness of local culture is an asset in developing product attributes and as an iconic specialty. The acquisition of designs based on local culture adopted will strengthen the identity of creative products and enrich new ideas to be applied as variations of the design on creative products (Hamzaoui \& Merunka, 2006). This local cultural wealth is an asset for SMEs to innovate in order to develop new products to be marketed, so that in the context of the creative industry it has been demonstrated that the LHDA will have a significant influence on innovative entrepreneurial orientation (Tan, 2002; Zheng, 2011) and also the root of the ethical concept inherent in being the presence of a spirit of entrepreneurship (Cruz et al., 2015; Hermawan et al., 2018; O’Dwyer et al., 2010). The fifth hypothesis is that there is a significant influence between LHDA on IBIE. 


\section{Methodology}

\subsection{Sample}

This empirical study is based on selected micro creative industry sectors as population, given that the theoretical framework adopted refers to resource-based and entrepreneurship theories that emphasize the use of resources in the form of cognitive abilities of individual entrepreneurs in facilitating the management of heterogeneous outputs. In the process, these theories emphasize the availability of the elaboration of various resources that make it possible to create innovation (Alvarez \& Busenitz, 2001; Kellermanns et al., 2016). The sample is a local design based UKM such as batik fashion, advertising, software, and handicraft sectors. The amount of creative SMEs in Indonesia reaches 57.19 million spread across various creative industry sectors with traditional fashion highlights. Batik as part of the Indonesian fashion industry is recognized by UNESCO as the Masterpieces of the Oral and the Intangible Heritage of Humanity (2009) and is a prima donna micro-industry sector in Indonesia. The population of batik industry accounting for $1 \%$ of the total in 2017. The batik industry requires superior skills in motifs and designs, both motifs and contemporary motifs. The research sample was taken from 180 SME owners in creative industry clusters from cities with strong local wisdom nuances such as Jogjakarta, Surakarta, and Denpasar. Purposive sampling method is employed using questionnaires and collected by surveyors.

Creative SMEs in the sample has been established for more than three years. To reduce the risk of common method bias, the surveyor becomes a facilitator for respondents on a non-self-assessment basis with a simple cross-check through line management and subordinates, in addition to that, procedural remedies technique is applied for re-verification of the respondent for the answers

Table 1. Characteristics of respondents

\begin{tabular}{|l|c|c|}
\hline & Number of Firms & Percent \\
\hline (a) Location & & \\
\hline Denpasar & 45 & 32.6 \\
\hline Surakarta & 37 & 26.8 \\
\hline Jogjakarta & 56 & 40.6 \\
\hline (b) Industrial Type & & \\
\hline Batik Fashion & 43 & 31.2 \\
\hline Handicraft & 42 & 30.4 \\
\hline Software and Game & 25 & 18.1 \\
\hline Advertising & 28 & 20.3 \\
\hline (c) Total number of & & \\
Employee & & 63.0 \\
\hline 1 to less than 5 & 87 & 26.8 \\
\hline 10 to less than 20 & 37 & 10.1 \\
\hline 30 above & 14 & 100.0 \\
\hline Total & 138 & \\
\hline
\end{tabular}

given (Podsakoff et al., 2003). In the data processing, the number of questionnaire data returned was 170 out of 180 and the adjustment of the outlier data to the number of samples became 138 (74.4\%). This number already has a sufficient sample (Hair, 2011), where the minimum sample sufficiency is 105 obtained from the multiplication of 15 item scales with an index value of 7 .

Table 1 revealed that the majority of the samples are coming from the batik fashion industry $(31.2 \%)$ and Handicraft (30.4\%) which is dominated in Jogjakarta City, Indonesia (40.6\%). It represents the condition of Indonesia's economy that is supported by the creative industry and the fashion sub-sector gives the largest contribution to the GDP. Besides, it is found that most of the industries have the total of employees less than five (63.0\%).

\subsection{Measurement}

This study is an exploratory study based on respondents' perceptions taken as samples. The empirical model in this study was built on four variables, namely: IT, LHDA, OP and also IBIE as the novelty of the concepts offered in this study. The IT variable has a dimension referred to by previous researchers, in the form of strategic IT awareness, IT investment, IT knowledge transfer, IT knowledge creation (Gold et al., 2001; Real et al., 2006; Tippins \& Sohi, 2003) The OP variable emphasizes non-financial performance indicators such as market share growth, sales target achievement levels, organizational performance indicators are widely used by previous researchers (Lee et al., 2012; Mendejin \& Arastekhoo, 2017; Mills \& Smith, 2011; Mohammad et al., 2012). Measurement of LHDA variables emphasizes on two main dimensions, namely the existence of the induction of local ornaments on products as well as the dimensions of national cultural commitment. Measurement on the novelty of entrepreneurial orientation variables in the form of IBIE concept has two main dimensions of innovation orientation (Roig-Tierno et al., 2015; Valentina et al., 2015; Zsuzsanna \& Herman, 2012) and orientation to create the product is hard to be imitated (Cruz et al., 2015; Hermawan et al., 2018), this second dimension emphasizes the spirit of Inimitable creative products created by SMEs. The analysis tool uses an Structural Equation Modelling (SEM), with 15 item scales with a score of 1-10 on the interval scale used for all constructs on the full model. SEM analysis result will provide the estimates of the empirical model which include direct and indirect effect between variables.

\section{Data analysis and result}

Sample adequacy test that is able to be done by structural equation model minimum statistical tools is 18 indicators multiplied by a weighted index of $5-10$ (Hair, 2011) with a minimum sample required of $90-180$ respondents, testing the AMOS Hoetler program obtained a value of 139 so that it was concluded 138 samples owned is enough to be processed in the model. The number of observed variables 
is 15 and the unobserved variable is 22 , the exogenous variable is 19 while the endogenous variable is 18 variables, obtained a distinct sample moment 120 , a distinct parameter to be estimate 36, Degree of Freedom (DF): 84 . In the assessment of normality variables, the range of skew is -0.2 to -0.9 (skew $<0.1$ ) with a range of CR 0.09 to 1.94 , which shows the data entered in the model is normally distributed. The determinant of sample covariance matrix obtained is 10078,821 (covariance matrix $>0.0$ ), therefore it can be concluded that there is no multicollinearity or singularity, therefore the data obtained is feasible to use.

Before compiling in the full model, the next step is to perform Confirmatory Factor Analysis (CFA) for all variables. In the IT construct obtained loading factors are BSMP1 (0.68), BSMP2 (0.66), BSMP3 (0.58), BIF1 (0.74), and BIF2 (0.52), loading factors for IBIE mediation variables are AIN1 (0.69), AIN2 (0.63), APR1 (0.56), loading factors for LHDA mediating variables are CRES (0.78), CLB (0.61), CEXP (0.63), CCHG (0.64) and loading factors for endogenous Organizational performance variables are ECS1 (0.82), ECS2 (0.78), EFP (0.63), all of which have factor loading values above 0.5 so that indicators can be declared valid and constructs can be used to represent variables. Goodness of Fit (GoF) by referring to the cut off Probability (Prob.), Goodness of Fit Index (GFI), Adjusted Goodness of Fit Index (AGFI), Tucker Lewis Index (TLI), and Root Mean Square Error of Approximation (RMSEA) seen in Table 2, that all the variables and constructs of CFA on each exogenous and endogenous variable are feasible to be applied to build a full structural model.

Table 2. CFA

\begin{tabular}{|l|c|c|c|c|c|c|}
\hline & Prob. & DF & GFI & AGFI & TLI & RMSEA \\
\hline IT & 0.280 & 5 & 0.982 & 0.946 & 0.985 & 0.043 \\
\hline IBIE & 0.275 & 1 & 0.994 & 0.966 & 0.993 & 0.037 \\
\hline LHDA & 0.792 & 2 & 0.998 & 0.992 & 1.037 & 0.000 \\
\hline OP & 0.038 & 1 & 0.980 & 0.879 & 0.918 & 0.156 \\
\hline
\end{tabular}

The use of a reliability coefficient based on modeling is recommended to be used as an alternative technique for identifying psychometric properties.

In SEM application regard to Table 3, the objective of using the reliability coefficient on the composite model is to be able to build a model that is following the data obtained, so that measurements on the Composite Reliability (CR) and Average Variance Extracted (AVE) calculations for each variable IT $(0.774 / 0.636)$, IBIE $(0.761 / 0.665)$, LHDA $(0.660 / 0.632)$ and OP $(0.789 / 0.743)$, which indicated that the value of $\mathrm{CR}>0.7$ and AVE $>0.5$, both of which were more than the cut off required for validity in the good discriminant category (Fornell \& Larcker, 1981) based on the Table 4. Furthermore, after the CFA meets the loading factor $>0.5$ and, meets the cut off standard value of GoF, the next step is to construct the constructs of these variables into a model as demonstrated in Figure 2.
Table 3. Validity and reliability construct

\begin{tabular}{|c|c|c|c|c|}
\hline $\begin{array}{l}\text { Constructs and their } \\
\text { respective items }\end{array}$ & Code & $\begin{array}{l}\text { Loading } \\
\text { Factor }\end{array}$ & AVE & CR \\
\hline Information Technology & IT & & & \\
\hline $\begin{array}{l}\text { Has clear rules for format- } \\
\text { ting or categorizing process } \\
\text { knowledge My organization } \\
\text { uses technology that allows. }\end{array}$ & BSMP1 & 0.68 & 0.774 & 0.636 \\
\hline $\begin{array}{l}\text { IT to retrieve and use } \\
\text { knowledge about its } \\
\text { products and process }\end{array}$ & BSMP2 & 0.66 & & \\
\hline $\begin{array}{l}\text { IT to retrieve and use } \\
\text { knowledge about its } \\
\text { markets and competition }\end{array}$ & BSMP3 & 0.58 & & \\
\hline $\begin{array}{l}\text { Employees to collaborate } \\
\text { with other persons inside } \\
\text { the organization }\end{array}$ & BIF1 & 0.74 & & \\
\hline $\begin{array}{l}\text { IT to search for new } \\
\text { knowledge }\end{array}$ & BIF2 & 0.52 & & \\
\hline $\begin{array}{l}\text { Inimitable-based Inno- } \\
\text { vative Entrepreneurship }\end{array}$ & IBIE & & & \\
\hline $\begin{array}{l}\text {... more than five-time per } \\
\text { year, my own SME was able } \\
\text { to create a new creative } \\
\text { product }\end{array}$ & AIN1 & 0.69 & 0.761 & 0.665 \\
\hline $\begin{array}{l}\text {... there is too difficult to } \\
\text { seek the product as like as } \\
\text { own product in the market }\end{array}$ & AIN2 & 0.63 & & \\
\hline $\begin{array}{l}\text { I used the own knowledges } \\
\text { to build the own design } \\
\text { with no plagiarism }\end{array}$ & APR1 & 0.56 & & \\
\hline $\begin{array}{l}\text { Local Heritages Design } \\
\text { Acquisition }\end{array}$ & LHDA & & & \\
\hline $\begin{array}{l}\text { The environment around } \\
\text { me was a reference for } \\
\text { influencing the variation in } \\
\text { my own product design }\end{array}$ & CRES & 0.78 & 0.660 & 0.632 \\
\hline $\begin{array}{l}\text { My products use attributes } \\
\text { with distinctive local } \\
\text { ornament patterns }\end{array}$ & CLB & 0.61 & & \\
\hline $\begin{array}{l}\text { I was able to make a lot of } \\
\text { patterns variation for my } \\
\text { own design with the local } \\
\text { heritage ornaments }\end{array}$ & CEXP & 0.63 & & \\
\hline $\begin{array}{l}\text {... committed to adopting } \\
\text { local cultural heritage rather } \\
\text { than the flowering trend of } \\
\text { foreign culture }\end{array}$ & $\mathrm{CCHG}$ & 0.64 & & \\
\hline $\begin{array}{l}\text { Organizational } \\
\text { Performance }\end{array}$ & OP & & & \\
\hline $\begin{array}{l}\text { My own product was easily } \\
\text { accepted by the market }\end{array}$ & ECS1 & 0.82 & 0.789 & 0.743 \\
\hline $\begin{array}{l}\text { The organization meets its } \\
\text { performance targets }\end{array}$ & ECS2 & 0.78 & & \\
\hline $\begin{array}{l}\text { The organization has } \\
\text { achieved profits that always } \\
\text { increase every year }\end{array}$ & EFP & 0.63 & & \\
\hline
\end{tabular}


Table 4. Discriminant validity

\begin{tabular}{|l|c|c|c|c|c|c|}
\hline & Mean & Standard Deviation & ITC & IBIE & LHDA & OP \\
\hline Information Technology & 7.691 & 1.34 & 0.880 & & & \\
\hline Inimitable-base Innovative Entrepreneurship & 8.029 & 1.33 & 0.631 & 0.872 & & \\
\hline Local Heritage Design & 7.914 & 1.29 & 0.533 & 0.594 & 0.812 & \\
\hline Organizational Performance & 7.917 & 1.33 & 0.519 & 0.470 & 0.713 & 0.888 \\
\hline
\end{tabular}

Note: The diagonal is a square root of AVE.

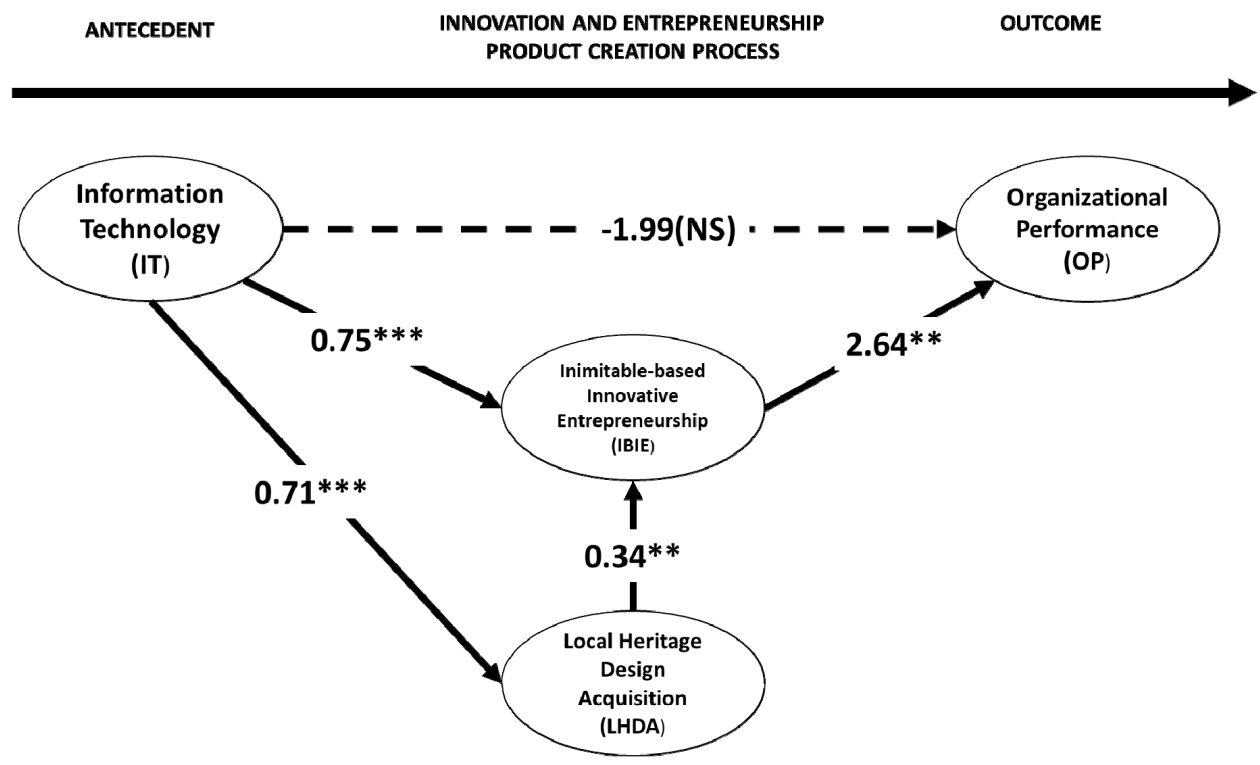

Note: ${ }^{* *}$ significant $0.01,{ }^{* *}$ significant 0.05 and (NS) no significant.

Figure 2. Empirical model

The full GoF model obtained DF 84 ( $\alpha=0.005$, ChiSquare Table $=148.77$ ) with the resulting Chi-Square Model value of 115,558, this value is far below the adequacy prerequisites required in the cut-off standard. Prob. = 0.013, CMIN / DF (1.736), GFI (0.901), AGFI (0.859), CFI (0.959), TLI (0.949), RMSEA (0.052) with the distribution of these values, the full model meets the GoF, so the model can be generalized to test concepts built in the hypotheses. Calculations for the full model show the effect of IT on OP $(\beta=-1.989, \mathrm{SE}=1.47, \mathrm{CR}=4.679)$ has a Prob. of 0.085, which refers to the hypothesis offered at $\mathrm{H} 1$ as unfulfilled, meaning that there is no significant effect between IT and OP.

Figure 2 revealed that $\mathrm{H} 1$ is accepted, which means that IT has no significant effect on OP $(\beta=-1.989, \mathrm{SE}=$ $1.356, \mathrm{CR}=-1.723)$. The effect of IT on IBIE $(\beta=0.747$, $\mathrm{SE}=0.159, \mathrm{CR}=4.359$ ) with Prob. 0.000 , this relation is significant at the level of 0.001 (two-tailed) which means $\mathrm{H} 2$ is accepted, there is a significant influence of IT on IBIE. In the $\mathrm{H} 3$ test about the influence of IBIE on OP $(\beta=3.341, \mathrm{SE}=1.424, \mathrm{CR}=2.346)$ with Prob. 0.019. So, that it can be said that the $\mathrm{H} 2$ hypothesis is accepted and significant at the 0.05 level. Hypothesis testing $\mathrm{H} 4$ shows there is a significant influence between IT on the LHDA $(\beta=2.645, \mathrm{SE}=0.147, \mathrm{CR}=4.679)$ with Prob. 0.000 so that the hypothesis $\mathrm{H} 4$ is accepted. In testing the hypothesis $\mathrm{H} 5$, regarding the significant influence of LHDA on IBIE $(\beta=0.337, \mathrm{SE}=0.132, \mathrm{CR}=0.440)$ with Prob. 0.015 , which has significance at the 0.05 level, so that H5 is declared acceptable, there is a significant effect between LHDA and IBIE.

Table 5. Direct, indirect dan total effect, explain variances test for endogenous variables

\begin{tabular}{|l|c|c|c|}
\hline $\begin{array}{c}\text { Effect on the } \\
\text { endogenous } \\
\text { variable }\end{array}$ & Direct Effect & $\begin{array}{c}\text { Indirect } \\
\text { Effect }\end{array}$ & Total Effect \\
\hline Effects on IBIE & 0.747 & 0.238 & 0.985 \\
\hline H2: IT & 0.337 & - & 0.337 \\
\hline H5: LHDA & 0.706 & - & 0.706 \\
\hline Effect on LHDA & \multicolumn{5}{|l}{} \\
\hline H4: IT & $1.989(\mathrm{NS})$ & 2.604 & 0.615 \\
\hline Effect on OP & 2.645 & - & 2.645 \\
\hline H1: IT &
\end{tabular}

Table 5 confirmed the success of IBIE as a mediation variable between IT and OP amount to 2.604. Another way of indirect effect between IT and OP is through LHDA as 
mediator. However, LHDA (0.706) cannot directly affect OP but through IBIE (0.337). It strengthens the significant role of IBIE in this model.

\section{Discussion}

Shown in Figure 2 that $\mathbf{H 1}$ is about the relation of IT to $\mathrm{OP}$ is rejected. This means, empirically there is no significant influence between IT as a tool of knowledge creation, knowledge transfer, knowledge storage on OP $(\beta=-2.377$, $\mathrm{CR}=-1.723$, value $=0.085)$. This empirical fact corroborates the opinion at the first pole, in line with studies (Powell \& Dent-Micallef, 1997), that IT capability cannot indeed be a stand-alone variable. IT requires variable mediation to be able to create the significance of competitive advantage in organizations (Hermawan et al., 2019b). To obtain optimal leverage, IT must be elaborated with other elements and resources of the organization (Chiu \& Chen, 2016; Matin \& Sabagh, 2015; Mazidi et al., 2014; Mills \& Smith, 2011; Roldán et al., 2018; Shin, 2001; Smith, 2008; Tippins \& Sohi, 2003). The negative value generated by the influence relation built between IT and OP is also confirmed in the study (Mills \& Smith, 2011), the conclusions of this finding reaffirm that the influence of IT has an inverse and insignificant relation to OP.

$\mathrm{H} 2$ testing of the effect of IT on IBIE novelty obtained value ( $\beta=0.695, C R=4.359$, value significant $<0.001$ ). This value addresses the significant influence between IT and IBIE. The role of IT to facilitate creation, transfer and knowledge storage has an influence on entrepreneurship that is oriented to Inimitable innovation. With IT infrastructure that provides knowledge creation support, entrepreneurs are able to convert it into unique creative products that are not easily imitated. Entrepreneurs who have fresh ideas are built through the role of entrepreneurs as organizational leaders (Abbas, 2018; Ndungu et al., 2017; Todd \& Javalgi, 2007). The existence of an optimal IT has worked to trigger ideas that are always renewable and the solution of bottle-neck problems. IT facilitates producing creative designs easily and quickly, giving a role in its capacity as a resource to stimulate entrepreneurs to innovate continuously. On the other hand, the concept of Inimitable is an ethical entrepreneur concept that must exist in entrepreneurs to build their business. The spirit of building unique products encourages SMEs to build design independence, becoming a pioneer of a trendsetter (Cruz et al., 2015; Hermawan et al., 2018), the emphasis of this concept is offered to encourage the reputation of creative entrepreneurs so that it raises social appreciation, business ethics, self-respect for the creative design it finds. In this domain, IT has a significant influence on the IBIE variable.

H3 IBIE influence on OP $(\beta=3.341, \mathrm{CR}=2.346$, $\mathrm{t}$ value $=0.019)$ which has a significant influence at the 0.05 level Wang (2008) confirmed in his research on entrepreneurial orientation, which in his study found a significant influence on OP. Likewise in IBIE being tested, it concludes that IBIE also shows a significant influence on OP.
H4 examines the influence of IT on the uptake of local culture-based design ornaments for creative industry products $(\beta=0.686, C R=4.679$, value significant $<0.001)$, providing the hypothesis conclusions are accepted. There is an influence between IT on LHDA, which has been confirmed in studies (Lu et al., 2011; Schoales, 2006). IT has encouraged the adoption of local culture-based designs into creative products such as fashion, software, games, and handicraft. The image processing application infrastructure makes it easy for entrepreneurs to create variations based on local cultural patterns to convert them into attractive creative products. So that the existence of IT provides a stimulant for the birth of motifs and patterns of design nuanced local culture to be embedded in the design of creative products.

H5, testing the relationship of the effect of LHDA on IBIE $(\beta=0.322, \mathrm{CR}=2.440$, $\mathrm{t}$ value $=0.015$, value significant $>0.05)$. It was concluded that $\mathrm{H} 5$ was accepted, which means that there was a significant influence of LHDA on IBIE. The acquisition of local heritages design on products on both dimensions will strengthen IBIE. Local design enhances the strengthening of variations in ornament patterns, becoming a design option as well as forming a variety of ideas, design variants and inventory options in creative product creations adopted from the local culture. This is triggering the birth of innovation in new products (Lu et al., 2011; Tan, 2002; Zheng, 2011). On the other hand, local culture will be an asset that makes creative products unique, entrepreneurs do not need to plagiarize the designs of other people's work, because the peculiarities of local heritages ornaments have automatically become inimitable different power from the product design side with its competitors (Conner, 1991; Di Pietro et al., 2015; Valentina et al., 2015). To strengthen the IBIE variable, SMEs only need to adopt then create local nuance-based designs with enriching its variations, so that the local heritages ornament will truly become an organizational resource asset to achieve Inimitable innovation. As Table 1 shows, the structural equation model for IT influence on OP obtained direct effect values $(-2.337$, not significant), indirect effects (3.059) and total effects (0.772), as well as in Figure 2, which offers the IBIE middle concept. Thanks to the empirical facts empirically proven IBIE has been able to act as a full mediation variable between IT and OP. IBIE succeeded in providing an explanation filling the empty space of the gap about the influence of IT on OP. The novelty offered by IBIE will contribute to the body of knowledge research in the field of creative entrepreneurship.

\section{Conclusions and managerial implications}

IT cannot be a stand-alone concept. In the context of creative entrepreneurship, the role of IT does not directly provide a significant influence on OP. IT needs to be elaborated with other organizational elements and processes to dynamically leverage the role of its role in the organization. The novelty of the concept of entrepreneurship as 
a novelty, called IBIE, has been empirically tested and is able to become a full variable mediator. The concept of IBIE becomes a trigger so that IT resources significantly influence OP. In managerial implications, entrepreneurs need to strengthen their commitment to building designs independently, using materials in their immediate environment in the form of culture to provide fresh, original ideas to be able to create consistently. IT capability will take the role of strategic tools in influencing the acquisition of design nuanced motif patterns absorbed from local-national heritages. IT infrastructure in the form of hardware and software helps enrich patterns, variations in motives, builds a repository of design ideas that will be inputted as product attributes. IT facilitates visual simulations and helps create many variations of a limited archetype. Managerial implications, in this case, entrepreneurs need to provide a portion of the training to enough technical personnel in the IT field to strengthen their competence in operating IT. Implications of applications based on vector and kaleidoscope graph algorithms need to be used to build patterns such as contemporary batik patterns in fashion. IT can also be empowered to build good connections with colleagues and be able to open new market access in the view of the marketing needs of creative products.

LHDA has an influence on IBIE variable, local design becomes a national asset that can be adopted by local entrepreneurs, because of the specific local heritages content, the managerial implications of the creative products produced are iconic national eco-tourism products, the nuances of local heritage will automatically be attached to the product and immediately gives a different power from similar products owned by competitors. In the model offered in Figure 2, the innovation process in addition to being able to leverage using IT, then this process can also be strengthened through the enrichment of local design nuances acquisition. In the achievement of OP through IT channels which are gaps, it can be approached efficiently using concept mediation in the form of IBIE (direct effect 3341) and LHDA (indirect effect 1.077) or through both (indirect effect 3.059). The use of the IBIE concept through the LHDA channel will encourage the mediation of OP through IT to be optimal.

\section{Limitation and future research}

This study has several limitations, first in the sample, the number of sectors in this creative industry only amounts to 4 sectors namely fashion, advertising, software and handicraft, and all sectors are SMEs with a small and medium business scale which have a maximum of 30 staff employees only, in this paper in other creative industries, even though they are based on design, they have not been accommodated, such as architecture, performance art, publishing, photography or film, so that in future research it is necessary to confirm these findings in other creative industry sectors on a large company scale. The second limitation, the OP variable is only measured by perception on the non-financial dimension. Future research requires ratio data that measures performance outcomes such as $\mathrm{ROI}$ and ROA, it is necessary to reconfirm the influence of IT on the IBIE mediated OP whether it remains consistent. Although in the LHDA model it acts as a moderate mediation between IT and IBIE, the indirect effect of IT on IBIE mediated by LHDA is still smaller than the direct effect, so that in future research directions to strengthen IBIE can pay attention to other issues that may be more able to dynamize the role IT capabilities, such as social capital relationships, organizational learning and knowledge-based collaboration sharing to flush the induction of knowledge in organizations.

\section{References}

Abbas, S. A. (2018). Entrepreneurship and information technology businesses in economic crisis. Entrepreneurship and Sustainability, 5(3), 682-692.

https://doi.org/10.9770/jesi.2018.5.3(20)

Ainin, S., Naqshbandi, M. M., \& Dezdar, S. (2016). Impact of adoption of Green IT practices on organizational performance. Quality \& Quantity, 50(5), 1929-1948.

https://doi.org/10.1007/s11135-015-0244-7

Alaarj, S., Abidin-Mohamed, Z., \& Bustamam, U. S. B. A. (2016). Mediating role of trust on the effects of knowledge management capabilities on organizational performance. Procedia Social and Behavioral Sciences, 235, 729-738.

https://doi.org/10.1016/j.sbspro.2016.11.074

Almazán, D. A., Tovar, Y. S., \& Quintero, J. M. M. (2017). Influence of information systems in organizational performance. Contaduría y Administración, 62(2), 303-320.

https://doi.org/10.1016/j.cya.2016.07.005

Alvarez, S. A., \& Busenitz, L. W. (2001). The entrepreneurship of resource-based theory. Journal of Management, 27(6), 755775. https://doi.org/10.1177/014920630102700609

Barba-Sanchez, V., Calderón-Milán, M. J., \& Atienza-Sahuquillo, C. (2018). A study of the value of ICT in improving corporate performance: a corporate competitiveness view. Technological and Economic Development of Economy, 24(4), 1388-1407. https://doi.org/10.3846/tede.2018.3114

Barney, J. (1991). Firm resources and sustained competitive advantage. Journal of Management, 17(1), 99-120. https://doi.org/10.1177/014920639101700108

Baumol, W. J. (2010). The microtheory of innovative entrepreneurship. Princeton University Press. https://doi.org/10.1515/9781400835225

Bilan, Y., Mishchuk, H., Samoliuk, N., \& Grishnova, O. (2019). ICT and economic growth: Links and possibilities of engaging. Intellectual Economics, 13(1), 93-104. https://doi.org/10.13165/IE-19-13-1-07

Cantino, V., Devalle, A., Cortese, D., Ricciardi, F., \& Longo, M. (2017). Place-based network organizations and embedded entrepreneurial learning: Emerging paths to sustainability. International Journal of Entrepreneurial Behavior \& Research, 23(3), 504-523. https://doi.org/10.1108/IJEBR-12-2015-0303

Chang, T.-C., \& Chuang, S.-H. (2011). Performance implications of knowledge management processes: Examining the roles of infrastructure capability and business strategy. Expert Systems with Applications, 38(5), 6170-6178.

https://doi.org/10.1016/j.eswa.2010.11.053 
Chege, S. M., Wang, D., \& Suntu, S. L. (2020). Impact of information technology innovation on firm performance in $\mathrm{Ke}$ nya. Information Technology for Development, 26(2), 316-345. https://doi.org/10.1080/02681102.2019.1573717

Chiu, C.-N., \& Chen, H.-H. (2016). The study of knowledge management capability and organizational effectiveness in Taiwanese public utility: the mediator role of organizational commitment. SpringerPlus, 5(1), 1520.

https://doi.org/10.1186/s40064-016-3173-6

Choe, J. (2016). The relationships among strategic performance measurement systems, IS strategic alignment, and IT infrastructure for knowledge management. Global Business \& Finance Review (GBFR), 21(1), 56-72.

https://doi.org/10.17549/gbfr.2016.21.1.56

Conner, K. R. (1991). A historical comparison of resource-based theory and five schools of thought within industrial organization economics: do we have a new theory of the firm? Journal of Management, 17(1), 121-154. https://doi.org/10.1177/014920639101700109

Cruz, J., Sousa, P., \& Wilks, D. C. (2015). Entrepreneurial intentions and attitudes towards plagiarism. Journal of Academic and Business Ethics, 10, 1-13.

Cuevas-Vargas, H., Estrada, S., \& Larios-Gómez, E. (2016). The effects of ICTs as innovation facilitators for a greater business performance. Evidence from Mexico. Procedia Computer Science, 91, 47-56. https://doi.org/10.1016/j.procs.2016.07.040

Davi, N., Jorge, M., \& Edgard, D. B. (2013). Engaging environments: tacit knowledge sharing on the shop floor. Journal of Knowledge Management, 17(2), 290-306. https://doi.org/10.1108/13673271311315222

Di Pietro, L., Guglielmetti Mugion, R., Mattia, G., \& Renzi, M. F. (2015). Cultural heritage and consumer behaviour: a survey on Italian cultural visitors. Journal of Cultural Heritage Management and Sustainable Development, 5(1), 61-81.

https://doi.org/10.1108/JCHMSD-03-2013-0009

Emadzadeh, M. K., Afzali, N., Bagheri, A., Rahimpoor, M., Ezadi, F., \& Rahmani, M. (2013). Effect of intellectual capital on firm performance. International Journal of Academic Research in Accounting, Finance and Management Sciences, 3(2), 98-103.

Feeny, D. F., \& Ives, B. (1990). In search of sustainability: reaping long-term advantage from investments in information technology. Journal of Management Information Systems, 7(1), 27-46. https://doi.org/10.1080/07421222.1990.11517879

Fornell, C., \& Larcker, D. F. (1981). Evaluating structural equation models with unobservable variables and measurement error. Journal of Marketing Research, 18(1), 39-50. https://doi.org/10.2307/3151312

Gold, A. H., Malhotra, A., \& Segars, A. H. (2001). Knowledge management: An organizational capabilities perspective. Journal of Management Information Systems, 18(1), 185-214. https://doi.org/10.1080/07421222.2001.11045669

Hair, J. F. (2011). Multivariate data analysis: an overview BT international encyclopedia of statistical science (pp. 904-907). M. Lovric (Ed.). Springer.

https://doi.org/10.1007/978-3-642-04898-2_395

Hamzaoui, L., \& Merunka, D. (2006). The impact of country of design and country of manufacture on consumer perceptions of bi-national products' quality: an empirical model based on the concept of fit. Journal of Consumer Marketing, 23(3), 145155. https://doi.org/10.1108/07363760610663303

Hermawan, I., Sartono, N. G., \& Khakim, L. (2016). Open innovation on entrepreneurial knowledge intermediation through social media creative development: a case study of creative cities in Indonesia. The Social Sciences, 11(18), 4378-4383.
Hermawan, I., Sartono, S., Hidayat, F., \& Suharmanto, S. (2019a). Model of consumer trust, technology anxiety, sales service support, and other in features e-marketplace system to built customer satisfaction. In International Conference of Ethics on Business, Economics, and Social Science (ICEBESS 2018) (pp. 73-79). Yogyakarta, Indonesia. https://doi.org/10.2991/ icebess-18.2019.13

Hermawan, I., Suharnomo, S., Sartono, S., \& Hindrawati, G. (2019b). Knowledge-based active interaction as a mediation of social media in establishing work performance: A learning perspective. International Journal of Innovation, Creativity and Change, 9(10).

Hermawan, I., Sartono, S., \& Khakim, L. (2018). Entrepreneur capability in Pekalongan city: issues of gender, local culture and anti plagiation spirit for creative community. In E3S Web of Conferences (pp. 73, 10004). Semarang, Indonesia. https://doi.org/10.1051/e3sconf/20187310004

Hermawan, I., Suharnomo, S., Sartono, S., \& Hindrawati, G. (2020). Social network as antecedents collective cyber learning for fostering creative performance: a perspective organizational learning theory. International Journal of Advanced Science and Technology, 29(2), 490-502.

http://sersc.org/journals/index.php/IJAST/article/view/3221

Kellermanns, F., Walter, J., Crook, T. R., Kemmerer, B., \& Narayanan, V. (2016). The resource-based view in entrepreneurship: a content-analytical comparison of researchers' and entrepreneurs' views. Journal of Small Business Management, 54(1), 26-48. https://doi.org/10.1111/jsbm.12126

Kettinger, W. J., Grover, V., Guha, S., \& Segars, A. H. (1994). Strategic information systems revisited: a study in sustainability and performance. MIS Quarterly, 18(1), 31-58. https://doi.org/10.2307/249609

Kreiser, P. M., Marino, L. D., Kuratko, D. F., \& Weaver, K. M. (2013). Disaggregating entrepreneurial orientation: the nonlinear impact of innovativeness, proactiveness and risk-taking on SME performance. Small Business Economics, 40(2), 273291. https://doi.org/10.1007/s11187-012-9460-x

Lee, S., Kim, B. G., \& Kim, H. (2012). An integrated view of knowledge management for performance. Journal of Knowledge Management, 16(2), 183-203. https://doi.org/10.1108/13673271211218807

Lu, F., Tian, F., Jiang, Y., Cao, X., Luo, W., Li, G., Zhang, X., Dai, G., \& Wang, H. (2011). ShadowStory: creative and collaborative digital storytelling inspired by cultural heritage. In Proceedings of the SIGCHI Conference on Human Factors in Computing Systems (pp. 1919-1928). Vancouver, Canada. https://doi.org/10.1145/1978942.1979221

Luftman, J., Lyytinen, K., \& Zvi, T. ben. (2017). Enhancing the measurement of information technology (IT) business alignment and its influence on company performance. Journal of Information Technology, 32(1), 26-46. https://doi.org/10.1057/jit.2015.23

Lumpkin, G. T., \& Dess, G. G. (1996). Clarifying the entrepreneurial orientation construct and linking it to performance. Academy of Management Review, 21(1), 135-172. https://doi. org/10.5465/amr.1996.9602161568

Matheson, B. (2006). A culture of creativity: design education and the creative industries. Journal of Management Development, 25(1), 55-64. https://doi.org/10.1108/02621710610637963

Matin, E. K., \& Sabagh, P. (2015). Effects of knowledge management capabilities on organizational performance in iranian export companies. Mediterranean Journal of Social Sciences, 6(2), 240. https://doi.org/10.5901/mjss.2015.v6n2p240 
Matsuno, K., Mentzer, J. T., \& Özsomer, A. (2002). The effects of entrepreneurial proclivity and market orientation on business performance. Journal of Marketing, 66(3), 18-32. https://doi.org/10.1509/jmkg.66.3.18.18507

Mazidi, A. R. K., Amini, A., \& Latifi, M. (2014). The impact of information technology capability on firm performance; a focus on employeecustomer profit chain. Iranian Journal of Management Studies, 7(1), 95-120.

Medina-Quintero, J. M., Mora, A., \& Abrego, D. (2015). Enterprise technology in support for accounting information systems. An innovation and productivity approach. JISTEMJournal of Information Systems and Technology Management, 12(1), 26-44. https://doi.org/10.4301/S1807-17752015000100002

Meiliene, E., Neverauskaite, S., \& Aidis, R. (2015). Methodological aspects of compiling country's competitiveness through the aspect of technology-intensive innovative enterprises index. Procedia - Social and Behavioral Sciences, 213, 173-178. https://doi.org/10.1016/j.sbspro.2015.11.422

Mendejin, M. R., \& Arastekhoo, N. (2017). Investigating the effect of knowledge management (infrastructures and processes) on performance (Case Study: SAIPA Co.). International Journal of Applied Business and Economic Research, 15(5), 351-365.

Mills, A. M., \& Smith, T. A. (2011). Knowledge management and organizational performance: a decomposed view. Journal of Knowledge Management, 15(1), 156-171.

https://doi.org/10.1108/13673271111108756

Miranda, S. M., Lee, J.-N., \& Lee, J.-H. (2011). Stocks and flows underlying organizations' knowledge management capability: Synergistic versus contingent complementarities over time. Information \& Management, 48(8), 382-392. https:// doi.org/10.1016/j.im.2011.10.002

Mohammad, H. H., Mohammad, F. H., Ali, S., \& Ali, N. B. (2012). The influence of knowledge management capabilities on organizational performance: a study of private university in Malaysia. International Journal of Science and Research, 3(10), 355-360.

Müller-Bloch, C., \& Kranz, J. (2015). A framework for rigorously identifying research gaps in qualitative literature reviews [Conference presentation]. Thirty Sixth International Conference on Information Systems. Fort Worth, Texas.

Ndungu, S., Wanjau, K., Gichira, R., \& Mwangi, W. (2017). Moderating role of entrepreneurial orientation on the relationship between information technology competence and firm performance in Kenya. International Journal of Professional Business Review, 2(2), 1-22.

https://doi.org/10.26668/businessreview/2017.v2i2.59

O’Dwyer, M., Risquez, A., \& Ledwith, A. (2010). Entrepreneurship education and plagiarism: tell me lies, tell me sweet little lies. Journal of Small Business and Enterprise Development, 17(4), 641-651. https://doi.org/10.1108/14626001011088778

Omeluzor, S. U., Imam, A., \& Bamidele, I. A. (2014). Preservation of African culture in the information age. Information Impact: Journal of Information and Knowledge, 5(1), 82-90.

Pareja-Eastaway, M. (2016). Creative industries. Journal of Evolutionary Studies in Business, 1(1), 38-50.

https://doi.org/10.1344/jesb2016.1.j003

Podsakoff, P. M., MacKenzie, S. B., Lee, J. Y., \& Podsakoff, N. P. (2003). Common method biases in behavioral research: a critical review of the literature and recommended remedies. Journal of Applied Psychology, 88(5), 879-903. https://doi.org/10.1037/0021-9010.88.5.879
Powell, T. C., \& Dent-Micallef, A. (1997). Information technology as competitive advantage: the role of human, business, and technology resources. Strategic Management Journal, 18(5), 375-405. https://doi.org/10.1002/(SICI)10970266(199705)18:5<375::AID-SMJ876>3.0.CO;2-7

Rajapathirana, R. P. J., \& Hui, Y. (2018). Relationship between innovation capability, innovation type, and firm performance. Journal of Innovation \& Knowledge, 3(1), 44-55. https://doi.org/10.1016/j.jik.2017.06.002

Ramadan, B. M., Dahiyat, S. E., Bontis, N., \& Al-dalahmeh, M. A. (2017). Intellectual capital, knowledge management and social capital within the ICT sector in Jordan. Journal of Intellectual Capital, 18(2), 437-462. https://doi.org/10.1108/JIC-06-2016-0067

Real, J. C., Leal, A., \& Roldán, J. L. (2006). Information technology as a determinant of organizational learning and technological distinctive competencies. Industrial Marketing Management, 35(4), 505-521. https://doi.org/10.1016/j.indmarman.2005.05.004

Roig-Tierno, N., Alcázar, J., \& Ribeiro-Navarrete, S. (2015). Use of infrastructures to support innovative entrepreneurship and business growth. Journal of Business Research, 68(11), 22902294. https://doi.org/10.1016/j.jbusres.2015.06.013

Roldán, J. L., Real, J. C., \& Ceballos, S. S. (2018). Antecedents and consequences of knowledge management perfomance. The role of IT infrastructure. Intangible Capital, 14(4), 518535. https://doi.org/10.3926/ic.1074

Schoales, J. (2006). Alpha clusters: creative innovation in local economies. Economic Development Quarterly, 20(2), 162-177. https://doi.org/10.1177/0891242405285932

Sharma, R., \& Intan, I. (2008). Bridging the digital divide in Asia-challenges and solutions. International Journal of Technology, Knowledge \& Society, 1(3).

https://doi.org/10.18848/1832-3669/CGP/v01i03/55886

Shin, N. (2001). The impact of information technology on financial performance: the importance of strategic choice. European Journal of Information Systems, 10(4), 227-236. https://doi.org/10.1057/palgrave.ejis.3000409

Sinkovics, R. R., Sinkovics, N., Lew, Y. K., Jedin, M. H., \& Zagelmeyer, S. (2015). Antecedents of marketing integration in cross-border mergers and acquisitions: Evidence from Malaysia and Indonesia. International Marketing Review, 32(1), 2-28. https://doi.org/10.1108/IMR-07-2014-0211

Smith, J. (2008). Information technology's influence on productivity. Student Work, 13.

https://digitalcommons.unomaha.edu/studentwork

Tan, J. (2002). Culture, nation, and entrepreneurial strategic orientations: implications for an emerging economy. Entrepreneurship Theory and Practice, 26(4), 95-111. https://doi.org/10.1177/104225870202600406

Teece, D. J. (1986). Profiting from technological innovation: Implications for integration, collaboration, licensing and public policy. Research Policy, 15(6), 285-305.

https://doi.org/10.1016/0048-7333(86)90027-2

Tippins, M. J., \& Sohi, R. S. (2003). IT competency and firm performance: is organizational learning a missing link? Strategic Management Journal, 24(8), 745-761.

https://doi.org/10.1002/smj.337

Todd, P. R., \& Javalgi, R. (Raj) G. (2007). Internationalization of SMEs in India: Fostering entrepreneurship by leveraging information technology. International Journal of Emerging Markets, 2(2), 166-180. https://doi.org/10.1108/17468800710739234

Torkestani, M. S., Mazloomi, N., \& Haghighat, F. (2014). The relationship between information systems success, organizational 
learning and performance of insurance companies. International Journal of Business and Social Science, 5(10).

Ţurcan, R. V., Mäkelä, M. M., Sørensen, O. J., \& Rönkkö, M. (2010). Mitigating theoretical and coverage biases in the design of theory-building research: an example from international entrepreneurship. International Entrepreneurship and Management Journal, 6(4), 399-417. https://doi.org/10.1007/s11365-009-0122-7

Ulrich, D., Younger, J., Brockbank, W., \& Ulrich, M. (2012). HR from the outside in: Six competencies for the future of human resources. McGraw Hill Professional.

Valentina, V., Marius-Răzvan, S., Ioana-Alexandra, L., \& Stroe, A. (2015). Innovative valuing of the cultural heritage assets. Economic implication on local employability, small entrepreneurship development and social inclusion. Procedia Social and Behavioral Sciences, 188, 16-26. https://doi.org/10.1016/j.sbspro.2015.03.334

Wang, C. L. (2008). Entrepreneurial orientation, learning orientation, and firm performance. Entrepreneurship Theory and Practice, 32(4), 635-657.

https://doi.org/10.1111/j.1540-6520.2008.00246.x
Yunis, M., Tarhini, A., \& Kassar, A. (2018). The role of ICT and innovation in enhancing organizational performance: The catalysing effect of corporate entrepreneurship. Journal of Business Research, 88, 344-356.

https://doi.org/10.1016/j.jbusres.2017.12.030

Zhang, P., Zhao, K., \& Kumar, R. L. (2016). Impact of IT Governance and IT capability on firm performance. Information Systems Management, 33(4), 357-373. https://doi.org/10.1080/10580530.2016.1220218

Zhao, Y., Li, Y., Lee, S. H., \& Chen, L. B. (2011). Entrepreneurial orientation, organizational learning, and performance: evidence from China. Entrepreneurship Theory and Practice, 35(2), 293-317. https://doi.org/10.1111/j.1540-6520.2009.00359.x

Zheng, J. (2011). 'Creative Industry Clusters' and the 'Entrepreneurial City' of Shanghai. Urban Studies, 48(16), 3561-3582. https://doi.org/10.1177/0042098011399593

Zsuzsanna, S. K., \& Herman, E. (2012). Innovative entrepreneurship for economic development in EU. Procedia Economics and Finance, 3, 268-275.

https://doi.org/10.1016/S2212-5671(12)00151-7 